\title{
Starch composition, glycemic indices, antioxidant properties and carbohydrate hydrolyzing enzymes activities of African star apple fruit parts
}

\author{
Olubunmi B. Ajayi, Folake L. Oyetayo and Seun F. Akomolafe* ${ }^{*}$
}

\begin{abstract}
Background: African star apple (Chrysophyllum albidum) is a traditonal fruit, which is predominant in tropical regions with the fruit parts consumed by the populace and used in folklore to manage diabetes. However, the likely activity mechanism is still undetermined. The current study examined and compared the inhibitory abilities of African star apple fruit parts on selected key enzymes related to diabetes mellitus in the pancreas tissue of rat.

Methods: Inhibitory effect of aqueous extract (1:10 w/v) of African star apple fruit parts (pulp, cotyledon, seed coat and pulp coat) on the activities of a-amylase, a-glucosidase, as well as their starch composition, phenolic constituents, estimated glycemic index, and antioxidant properties were assessed.

Results: The fruit parts showed low sugar, eGl, amylose, and amylopectin contents. The analysis also showed that the fruit parts inhibited a-glucosidase and a-amylase activities and exhibited antioxidant properties. Furthermore, the fruit parts contain high concentrations of beta-amyrin acetate, eleagine, epicatechin, epigallocatechin, skatole, stigmasterol and tetrahydro - 2- methylharman as revealed by HPLC-DAD.

Conclusion: The fruit part low estimated glycemic indices, strong antioxidant properties, inhibition of a-amylase and a-glucosidase activities exhibited might be related to the bioactive compounds contained in the extract. This could also be a potential mechanism for the use in the prevention and management of type-2 diabetes.

Nevertheless, the African star apple pulp coat displayed the highest property in comparison to other parts of the fruit.
\end{abstract}

Keywords: African star apple fruit, a-Amylase, Diabetes mellitus, a-Glucosidase, Antioxidant, Acarbose

\section{Background}

The inability of $\beta$-pancreatic islet to produce sufficient insulin or un-utilization of insulin by the body is an underlining pathology of Diabetes mellitus. This civic medical challenge is linked to the rise in the rates of mortality and morbidity globally [1]. Nevertheless,

\footnotetext{
* Correspondence: purposefulseun@yahoo.co.uk; seun.akomolafe@eksu.edu.ng

Department of Biochemistry, Ekiti State University, Ado Ekiti, Ekiti State P.M.B. 5363, Nigeria
}

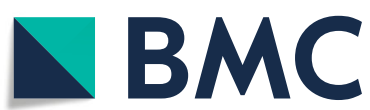

(c) The Author(s). 2020 Open Access This article is licensed under a Creative Commons Attribution 4.0 International License, which permits use, sharing, adaptation, distribution and reproduction in any medium or format, as long as you give appropriate credit to the original author(s) and the source, provide a link to the Creative Commons licence, and indicate if changes were made. The images or other third party material in this article are included in the article's Creative Commons licence, unless indicated otherwise in a credit line to the material. If material is not included in the article's Creative Commons licence and your intended use is not permitted by statutory regulation or exceeds the permitted use, you will need to obtain permission directly from the copyright holder. To view a copy of this licence, visit http://creativecommons.org/licenses/by/4.0/ The Creative Commons Public Domain Dedication waiver (http://creativecommons.org/publicdomain/zero/1.0/) applies to the data made available in this article, unless otherwise stated in a credit line to the data.

administrating carbohydrate hydrolyzing enzymes $(\alpha-$ glucosidase and $\alpha$-amylase) inhibitors (like acarbose) and/or reduction of carbohydrate consumption can decrease the absorption of glucose into the blood stream $[2,3]$. This will help to reduce glucose assimilation into the blood stream [3]. Acarbose, which is a synthetic drug currently in use for the inhibition of carbohydrate hydrolyzing enzymes has been reported to unveil several adverse influences. Herbs have been used by man from time immemorial to prevent and/or treat a wide array of 
disorders. Plant derived substances and/or plant extracts are naturally preferred by most individuals because they have lesser side effects and are cheaper, safer and tends to have better good health promotion than most synthetic drugs $[2,4-6]$.

The consumable part of the plants regarded to as fruits are available commercially as food which could be consumed in the raw form or processed into wine, and fruit juices [7].. Processing fruits generates large amounts of waste products which, according to reports, are rich in antioxidant [8]. In the tropics, especially Nigeria, a huge part of the country and notable for various fruits production, fruits are relished throughout the year. Oboh et al. [9] reported that the common fruits expended in Nigeria are orange, pineapple, African star apple, watermelon, pawpaw, mango, banana, carrot, cashew, among others.

African star apple (Chrysophyllum albidum G. Don (Sapotaceae)) is a traditional fruit which is predominantly found in Africa. The fruit is a lowland rain forest tree species which belongs to the family of Sapotaceae. It grows up to 25 to $37 \mathrm{~m}$ in height, with its girth between 1.5 to $2 \mathrm{~m} \mathrm{[10]}$. The fleshy pulp is widely consumed and used to manage diabetes in folklore [11]. In folkloric medicine, the plant bark is valuable in treating malaria and yellow fever [11], while the leaf has been used for treating stomach ache and diarrhea as well as a palliative. The leaves, barks, and roots are widely used for treating wounds, sprains, and bruises in the southern part of Nigeria. The root and seed extracts are useful in arresting bleeding from fresh wounds and helps to prevent wound contamination thereby, hastening the healing process [12]. According to report, the seed cotyledon exhibits both hypolipidemic and anti-hyperglycemic effects [13]. The fruit pulp can be freshly consumed and processed into stewed fruit, syrup, jam, soft drinks, and jellies. According to Akubugwo and Ugbogu [14], the fruit pulp of African star apple is highly rich in iron and ascorbic acid compared to other edible fruits. Oboh et al. [15] reported that the different parts of the fruit are potentially rich sources of functional foods and nutraceuticals which have neuroprotective properties due to their polyphenolic constituents and cholinesterases and monoamine oxidase activities, as well as their antioxidant properties. Ibrahim et al. [16] documented variations of phytochemicals and essential nutrients in edible parts of Chyrsophyllum albidum fruit, and afterward presumed that because of the phytochemicals and basic supplements as dissolvable and starch, insoluble fibers, arabinose and mineral components found in the pulp coat of Chrysophyllum albidum in correlation with the seed coat, cotyledon and fruit pulp has an incredible potential in adding to the sound growth and as supplementation in food industries. Abiodun and Oladapo [17] additionally detailed that the pulp coat and seed pericarp of the fruit which are generally disposed of as waste items during juice processing have been appeared to contain higher nutritive constituents than pulp part.

Also, in our previous study, we reported that the dietary supplementation of African star apple fruit pulp powder attenuated hyperglycemia and oxidative stress by altering biochemical parameters in type 2 diabetic condition [2]. There are no reported investigations into the toxicity activity of different parts of Chrysophyllum albidum fruit, except the butanolic extract of the seed cotyledon which has been reported by Shobo et al. [18] to cause mild to moderate toxicity at higher portions, and and subsequently inferred that while exploiting its numerous economic and therapeutic properties, there is the need to protect against aimless utilizations and to apply caution in the use of the seed cotyledon of Chrysophyllum albidum.

Additionally, previous reports have revealed the phenolic constituent and antioxidant properties of African star fruit $[15,19,20]$, but to the best of our knowledge, starch composition, estimated glycemic index (eGI), possible in vitro anti-hyperglycemic function of different parts of African star apple, and the likely biochemical mechanism that confirms their aptness as functional foods for managing of type- 2 diabetes are yet to be elucidated. Accordingly, the current study aims to compare African star apple fruit parts, the pulp, cotyledon, seed coat and pulp coat (Fig. 1) as a possible source of functional foods and nutraceuticals with anti-hyperglycemic function by investigating the effect of aqueous extract of African star apple fruit parts on $\alpha$-amylase and $\alpha$ glucosidase activities, as well as their starch composition, estimated glycemic index, phenolic constituents and antioxidant properties.

\section{Methods \\ Sample collection and identification}

The ripe African star apple fruits were purchased in March, 2018 from the Erekesan market in Ado Ekiti metropolis, Ekiti State, Nigeria. Authentication of the sample was carried out by Mr. Omotayo at the Department of Plant Science and Biotechnology, Ekiti State University, Ado-Ekiti where voucher specimen (voucher ID number UHAE 667) was deposited at the herbarium of the same Department.

\section{Aqueous extract preparation}

In order to eliminate any contaminants, the ripe African star apple fruits were thoroughly washed with clean water. The fruit parts (pulp, cotyledon, seed coat and pulp coat) were then separated and distinctly blended with distilled water $(1: 20 \mathrm{w} / \mathrm{v})$, centrifuged and filtered. The clear supernatant obtained after filtration was then 

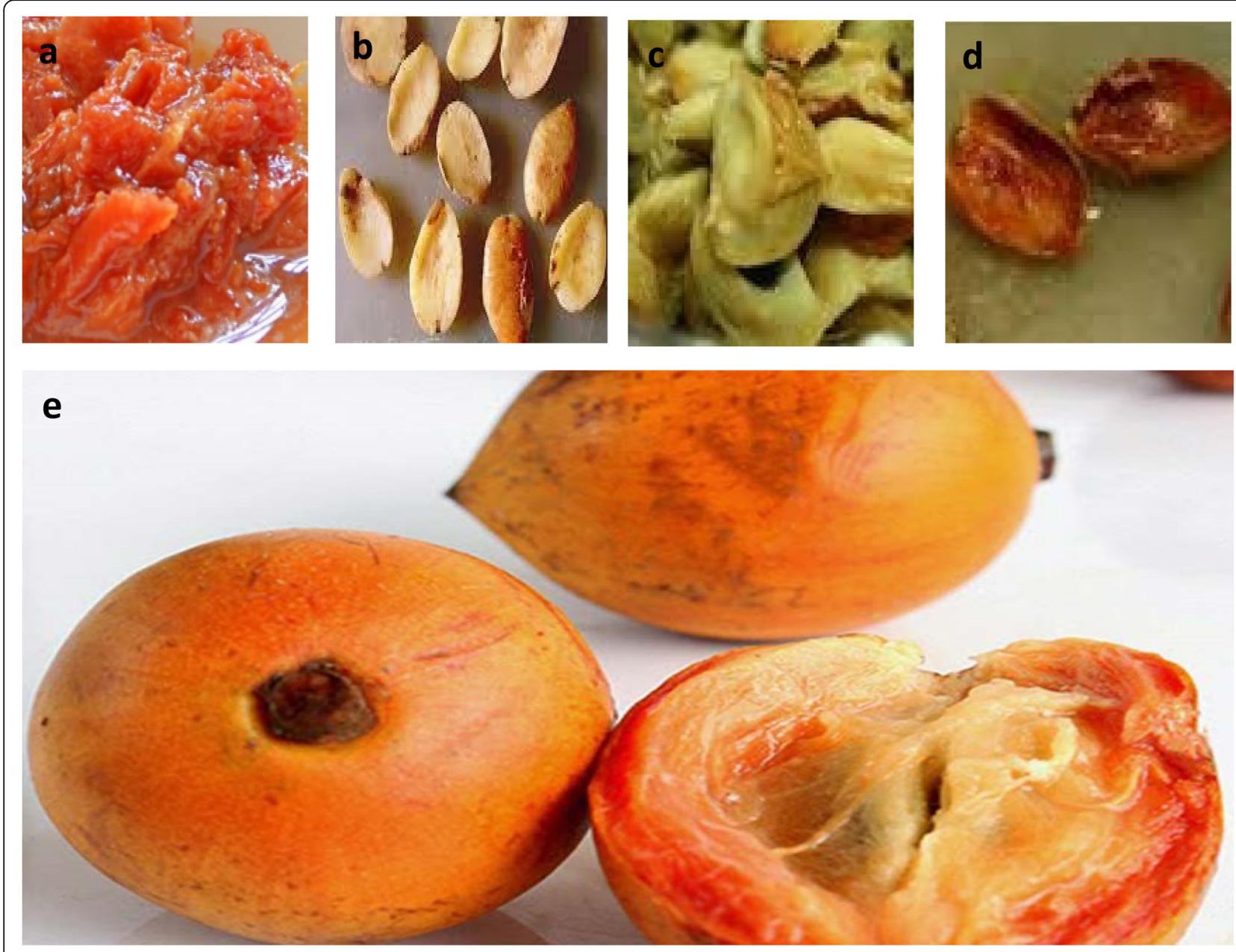

Fig. 1 African star apple fruit parts (a) Pulp (b) cotyledon (c) Seed coat (d) Pulp coat (e) Fruit

freeze-dried and placed in the refrigeration for subsequent analysis [21]. The fruits parts yield were $152.1 \mathrm{~g}$ dry sample/1000 g fresh fruit pulp, $126.5 \mathrm{~g}$ dry sample/ $1000 \mathrm{~g}$ fresh fruit cotyledon, $67.5 \mathrm{~g}$ dry sample/1000 g fresh fruit seed coat and $101.9 \mathrm{~g}$ dry sample/1000 $\mathrm{g}$ fresh fruit pulp coat for pulp, cotyledon, seed coat and pulp coat respectively. The freeze-dried fruit extract was then refrigerated at $-10^{\circ} \mathrm{C}$ and reconstituted for additional analysis.

\section{Determination of total flavonoid, total phenol, vitamin C contents and ferric reducing antioxidant property}

The study followed the procedure of Adefegha et al [22] in obtaining the total phenolic constituent and the total flavonoid composition of the extract. To calculate the total flavonoid composition, quercetin was used as standard. To obtain the total phenolic content, gallic acid was employed as the standard. Thus, the content was obtained as gallic acid equivalent (GAE). The procedure applied by Akomolafe and Ajayi [23] was used in obtaining the vitamin $\mathrm{C}$ composition of the extract. The composition was calculated in equivalence to standard ascorbic acid solution. Following the procedure of Akomolafe et al. [24], the samples' reducing property (based on the extract's capacity to reduce $\mathrm{FeCl}_{3}$ solution) was determined and calculated in equivalence to standard ascorbic acid solution.

\section{Determination of radicals (ABTS, DPPH, OH and NO) scavenging and $\mathrm{Fe}^{2+}$-chelating abilities}

Following the methods of Ademiluyi et al. [3] and Adefegha et al [22], two models were used in determining the sample's capacity to scavenge free radicals. These are the 1, 1-diphenyl-2 picrylhydrazyl (DPPH) [25] and 2,2'azino-bis (3-ethylbenzothiazoline-6-sulphonic acid) (ABTS) [3]. The samples' $\mathrm{Fe}^{2+}$ chelating ability was assessed using the procedure of Akomolafe et al. [26]. In evaluating the nitric oxide scavenging activity of the extracts, the method of Akomolafe et al. [27] was followed. To determine the extracts' ability to scavenge hydroxyl radical, the procedure of Halliwell et al [28] was followed. 


\section{Experimental animals}

Two adult male albino Wistar rats that weighed 202-210 g each were bought from the Department of Veterinary Medicine breeding colony, University of Ibadan, Nigeria. The rats were acclimatized at $25^{\circ} \mathrm{C}$, on a $12 \mathrm{~h}$ light $/ 12 \mathrm{~h}$ dark cycle for a fortnight ahead of the experiment (lights on from 19:00 to 7:00 h). In handling the rats, NIH Guide for the care and use of laboratory animals and the ethical Committee for Animal Experimentation of the University were strictly followed. The study was approved by Ekiti State University ethical committee with reference number AOO012BAJO01. All experimental procedures were performed according to the ARRIVE guidelines [29].

\section{Preparation of tissue homogenate and lipid peroxidation assay}

The procedure of Akomolafe et al. [30] and Akomolafe and Ajayi [23] were slightly modified and followed to prepare the pancreas homogenate and determine of thiobarbituric acid reaction assay. Two rats were placed under low doses of ketamine $(10 \mathrm{mg} / \mathrm{kg})$ and xylazine $(10 \mathrm{mg} / \mathrm{kg})$ anaesthesia administered via intraperitoneal (i.p.) injections, and euthanized by cervical dislocation, the rats were rapidly dissected. This was followed by rapid removal of the tissue, pancreas and washing with cold saline. The supernatant obtained from pancreatic tissue after preparation was used for the thiobarbituric acid reaction assay.

\section{a-Glucosidase and a-amylase activities assays}

To evaluate the impact of the extract on $\alpha$-glucosidase and $\alpha$-amylase activities, the methods utilized by Dada et al. [31] was adopted. Utilizing acarbose drug as a standard control, the extract's enzyme inhibitory impacts were expressed as percentage inhibition. This was determined after Equation (1):

$$
\mathrm{A}=\left[\mathrm{ABS}_{\text {ref }}-\mathrm{ABSs}_{\text {ample }}\right] / \mathrm{ABS}_{\text {ref }} \times 100
$$

\section{Sugar and starch determination}

Starch and sugar analyses were performed utilizing the method of Onitilo et al. [32]. The starch and total free sugar contents of the sample were determined from a glucose standard curve prepared alongside the sample.

Determination of the amylose and amylopectin content Amylose and amylopectin contents were determined utilizing the method of Juliano [33]. Amylose content was determined utilizing standard amylose. Amylopectin was determined after eq. (2) [33]:

$$
\text { amylopectin }=\text { starch value }- \text { amylose value }
$$

\section{Estimation of glycemic index}

The procedure applied by Brouns et al. [34] was utilized in obtaining the estimated glycemic index of the extract.

\section{HPLC analysis of phenolic components}

The method clarified by Kelley et al. [35] was utilized in evaluating the quantitative-qualitative examination of the phenolic components of the samples. To quantify it, peak regions were associated with concentrations as per the calibration curves. Results are accounted for as means \pm standard deviations of triplicate independent analyses.

\section{Data analysis}

The experiments conducted in triplicate were pooled and presented as mean \pm standard deviation. Comparison of Means was through a one-way ANOVA followed by Duncan's multiple range test. The least significant difference tests were conducted and accepted at $p \leq 0.05$.

\section{Results}

The sugar, amylose contents, starch, amylopectin contents, glycemic index and amylose/amylopectin ratio, of African star apple fruit parts

The free soluble starch contents (Table 1) of the fruit's parts ranged from $3.13 \mathrm{~g} / 100 \mathrm{~g}$ (pulp) to $4.42 \mathrm{~g} / 100 \mathrm{~g}$ (cotyledon) while the free soluble sugar (Table 1) ranged from $21.48 \mathrm{~g} / 100 \mathrm{~g}$ (cotyledon) to $28.63 \mathrm{~g} / 100 \mathrm{~g}$ (pulp) (Table 1). The amylose content of the fruits samples ranged from $2.01 \mathrm{~g} / 100 \mathrm{~g}$ (pulp coat) to $2.31 \mathrm{~g} / 100 \mathrm{~g}$

Table 1 The starch, sugar, amylose and amylopectin contents, amylose/amylopectin ratio, and glycemic index of African star apple fruit parts

\begin{tabular}{lllll}
\hline Sample & Pulp & Cotyledon & Seed coat & Pulp coat \\
\hline Starch $(\mathrm{g} / 100 \mathrm{~g})$ & $3.13 \pm 0.05^{a}$ & $4.24 \pm 0.27^{b}$ & $3.79 \pm 0.03^{a}$ & $3.58 \pm 0.13^{a}$ \\
Sugar $(\mathrm{g} / 100 \mathrm{~g})$ & $28.63 \pm 0.00^{a}$ & $21.48 \pm 0.04^{b}$ & $23.97 \pm 0.02^{b}$ & $21.66 \pm 0.03^{b}$ \\
Amylose $(\mathrm{g} / 100 \mathrm{~g})$ & $2.03 \pm 0.03^{a}$ & $2.31 \pm 0.02^{a}$ & $2.28 \pm 0.03^{a}$ & $2.01 \pm 0.02^{a}$ \\
Amylopectin $(\mathrm{g} / 100 \mathrm{~g})$ & $5.48 \pm 0.02^{a}$ & $5.25 \pm 0.02^{a}$ & $5.56 \pm 0.00^{a}$ & $5.15 \pm 0.05^{a}$ \\
Estimated glycemic index (\%) & $15.79 \pm 1.89^{a}$ & $29.10 \pm 0.67^{b}$ & $20.21 \pm 1.60^{c}$ & $13.63 \pm 0.42^{a}$ \\
Amylose/amylopectin ratio & 0.37 & 0.44 & 0.41 & 0.39 \\
\hline
\end{tabular}

Values represent mean \pm standard deviation $(n=3)$. Values with the same superscript letter within a row are not significantly $(p<0.05)$ different 
(cotyledon) (Table 1) while amylopectin content of the pulp coat of the fruit is lowered in comparison to other parts. The amylose/amylopectin ratio of the fruit parts ranges from 0.37 to 0.44 . The fruit parts had estimated glycemic indices ranging from 13.63 (pulp coat) to 29.10 (cotyledon) (Table 1).

\section{In-vitro antioxidant property of African star apple fruit parts}

Total phenolic content (Table 2) of fruit parts ranged from $7.56 \mathrm{mg} \mathrm{GAE} / \mathrm{g}$ (cotyledon) to $23.01 \mathrm{mg} \mathrm{GAE} / \mathrm{g}$ (pulp coat) while the total flavonoid content (Table 2) ranged from $2.27 \mathrm{mg} \mathrm{QE} / \mathrm{g}$ (cotyledon) to $5.79 \mathrm{mg} \mathrm{QE} / \mathrm{g}$ (pulp coat). The pulp coat had the highest vitamin $C$ content (13.03 mg AAE/g) compared to other fruit parts. The ability of the fruit parts to scavenge ABTS radical revealed that the pulp had the least value $(0.0370 \mathrm{mmol}$. TEAC/g) while the cotyledon had the highest value $(0.0548 \mathrm{mmol}$. TEAC/g) (Table 2). The reducing power of the fruit parts can be ranked in the order, pulp coat $(15.82 \mathrm{mg} \mathrm{AAE} / \mathrm{g})>$ pulp (10.23 mg AAE/g) > seed coat $(9.75 \mathrm{mg} \mathrm{AAE} / \mathrm{g})>$ cotyledon (5.52 mg AAE/g) (Table 2). The result showed that the fruit parts scavenged the $\mathrm{DPPH}, \mathrm{OH}^{*}$ and $\mathrm{NO}^{*}$ free radicals in a dose dependent manner (Table 3). Judging by the $\mathrm{IC}_{50}$ values, the $\mathrm{DPPH}$ scavenging ability of the fruit parts range from $1.32 \mathrm{mg} / \mathrm{mL}$ to $3.70 \mathrm{mg} / \mathrm{mL}$ with seed cotyledon $\left(\mathrm{IC}_{50}=3.70 \pm 0.57 \mathrm{mg} / \mathrm{mL}\right)$ having the least scavenging ability while pulp coat $\left(\mathrm{IC}_{50}=1.32 \pm 0.12 \mathrm{mg} /\right.$ $\mathrm{mL}$ ) had the highest (Table 3$)$. Hydroxyl $\left(\mathrm{OH}^{*}\right)$ radical scavenging ability of the fruits parts showed that the pulp coat $\left(\mathrm{IC}_{50}=3.69 \mathrm{mg} / \mathrm{mL}\right)$ had the highest $\mathrm{OH}^{*}$ radical scavenging ability and pulp $\left(\mathrm{IC}_{50}=6.12 \mathrm{mg} / \mathrm{mL}\right)$ the least (Table 3). The pulp coat $\left(\mathrm{IC}_{50}=0.39 \mathrm{mg} / \mathrm{mL}\right)$ had the highest NO radical scavenging ability while the pulp exhibited the least ability $\left(\mathrm{IC}_{50}=0.67 \mathrm{mg} / \mathrm{mL}\right)$. Also, pulp coat $\left(\mathrm{IC}_{50}=0.14 \mathrm{mg} / \mathrm{mL}\right)$ had the highest iron chelating ability and fruit pulp $\left(\mathrm{IC}_{50}=0.38 \mathrm{mg} / \mathrm{mL}\right)$ the least (Table 3$)$.

\section{Inhibition of $\mathrm{FeSO}_{4}$ and sodium nitroprusside induced lipid peroxidation in the pancreas}

The crude extracts from various parts of African star apple fruit led to a dose-dependent significant reduction $(P<0.05)$ in the content of $\mathrm{MDA}$ of $\mathrm{FeSO}_{4}$-stressed pancreas homogenates (Fig. 2a) with pulp coat $\left(\mathrm{IC}_{50}=\right.$ $0.34 \mathrm{mg} / \mathrm{ml}$ ) having the greatest inhibitory effect while the seed coat $\left(\mathrm{IC}_{50}=0.68 \mathrm{mg} / \mathrm{ml}\right)$ had the lowest when $\mathrm{IC}_{50}$ values were taken into account in Table 4. Similarly, the extract of the fruit parts repressed the production of MDA in the sodium nitroprusside induced pancreatic tissue in a dose-dependent way (Fig. 2b). Also, judging by the $\mathrm{IC}_{50}$ value in Table 4 , the crude extract of pulp coat had the highest inhibitory effect on sodium nitroprusside-induced lipid peroxidation in rat pancreas when compared to other fruit parts.

\section{Inhibition of $a$-amylase and $a$-glucosidase activities in rat pancreas}

The actions of carbohydrate hydrolyzing enzymes ( $\alpha$ amylase and $\alpha$-glucosidase) were inhibited by the fruits parts in a dose-dependent pattern (Table 5) with pulp coat exhibited the highest inhibition for $\alpha$-amylase (lower $\mathrm{IC}_{50}$ value of $1.39 \mathrm{mg} / \mathrm{mL}$ ) compared to seed coat $(4.16 \mathrm{mg} / \mathrm{mL})$, which had the least (Table 5). Nevertheless, acarbose still had the highest inhibitory effect on $\alpha$ amylase (Table 5). Similarly, the fruits parts inhibited $\alpha$ glucosidase activity in vitro in a dose-dependent pattern with the pulp coat had the highest inhibitory effect on $\alpha$ glucosidase (lower $\mathrm{IC}_{50}$ value of $1.35 \mathrm{mg} / \mathrm{mL}$ ) while cotyledon had the least $(2.29 \mathrm{mg} / \mathrm{mL})$ (Table 5). However, the inhibitory effect of the pulp coat was higher when compared with acarbose $(1.55 \mathrm{mg} / \mathrm{mL})$ (Table 5).

Polyphenolic constituents of African star apple fruit parts Table 6 presents the HPLC-DAD characterization of polyphenolic constituents contained in the fruit parts. As shown in Table 6, beta-amyrin acetate, eleagine, epicatechin, epigallocatechin, skatole, stigmasterol, and tetrahydro-2methyl harman are contained in all the fruits while gentisic acid, myricetin-3-rhamnoside, and procyanidin- $\mathrm{B}_{5}$ are other phenolic constituents in most of the fruits parts. The stuctures of the polyphenolic constituents found in the fruit parts are presented in Fig. 3.

\section{Discussion}

The poor awareness and research supporting the intake of fruits and vegetables amid diabetics has experienced

Table 2 Phytochemical contents, ABTS scavenging ability and Ferric reducing antioxidant property of African star apple fruit parts

\begin{tabular}{lllll}
\hline Samples & Pulp & Cotyledon & Seed coat & Pulp coat \\
\hline Total phenolic content (mg GAE/g) & $14.11 \pm 2.74^{a}$ & $7.56 \pm 2.74^{b}$ & $12.26 \pm 2.84^{c}$ & $23.01 \pm 2.65^{a}$ \\
Total flavonoid content (mg QE/g) & $5.31 \pm 0.05^{a}$ & $2.27 \pm 0.37^{b}$ & $3.69 \pm 0.18^{a}$ & $5.79 \pm 0.05^{a}$ \\
Vitamin C content (mg/g) & $7.26 \pm 0.11^{a}$ & $5.48 \pm 0.17^{a}$ & $5.54 \pm 0.28^{a}$ & $13.03 \pm 0.04^{b}$ \\
ABTS scavenging ability (X 100) (mmol. TEAC/g) & $3.70 \pm 0.03^{a}$ & $4.00 \pm 0.04^{a}$ & $3.97 \pm 0.02^{a}$ & $3.87 \pm 0.03^{a}$ \\
Ferric reducing antioxidant property (mg AAE/g) & $10.23 \pm 0.02^{a}$ & $5.52 \pm 0.58^{c}$ & $9.75 \pm 0.00^{c}$ & $15.82 \pm 1.14^{b}$ \\
\hline
\end{tabular}

Values represent mean \pm standard deviation $(n=3)$. Values with the same superscript letter within a row are not significantly $(p<0.05)$ different. GAE Gallic acid equivalent, $Q E$ Quercetin equivalent, TEAC Trolox equivalent antioxidant capacity, $A A E$ Ascorbic acid equivalent 
Table 3 Effective concentration causing 50\% antioxidant ability (I $\mathrm{C}_{50}$ values) of 1,1-diphenyl-2 picrylhydrazyl (DPPH), hydroxyl $(\mathrm{OH})$, nitric oxide (NO) radical scavenging abilities, iron chelating ability of fruits parts

\begin{tabular}{lllll}
\hline Sample & $\mathrm{DPPH}^{*}(\mathrm{mg} / \mathrm{Ml})$ & $\mathrm{OH}^{*}(\mathrm{mg} / \mathrm{ml})$ & $\mathrm{NO}^{*}(\mathrm{mg} / \mathrm{ml})$ & $\mathrm{Fe}^{2+}$ chelating ability $(\mathrm{mg} / \mathrm{ml})$ \\
\hline Pulp & $3.03 \pm 0.48^{b}$ & $6.12 \pm 2.07^{a}$ & $0.67 \pm 0.23^{a}$ & $0.38 \pm 0.10^{a}$ \\
Cotyledon & $3.70 \pm 0.57^{c}$ & $5.63 \pm 1.77^{b}$ & $0.40 \pm \pm 0.26^{b}$ & $0.26 \pm 0.15^{b}$ \\
Seed coat & $3.60 \pm 0.55^{c}$ & $5.73 \pm 1.77^{b}$ & $0.47 \pm 0.26^{b}$ & $0.16 \pm 0.04^{c}$ \\
Pulp coat & $1.32 \pm 0.12^{a}$ & $3.69 \pm 1.94^{c}$ & $0.39 \pm 0.04^{b}$ & $0.14 \pm 0.05^{c}$ \\
Ascorbic acid & $0.96 \pm 0.17^{a}$ & $2.25 \pm 0.89^{d}$ & $0.55 \pm 0.12^{b}$ & - \\
EDTA & - & - & - & $0.27 \pm 0.09^{b}$
\end{tabular}

*The radical scavenging abilities of the fruits parts were determined as described and expressed as percentage. The IC $\mathrm{C}_{50}$ (effective concentration causing $50 \%$ antioxidant ability) were calculated using nonlinear regression analysis. Values represent mean \pm standard deviation ( $n=3$ ). Values with the same letter within a column are not significantly different $(p>0.05)$. Positive control: ascorbic acid and EDTA (Ethylenediaminetetraacetic acid) were used for DPPH*, OH*, NO* and $\mathrm{Fe}^{2+}$ chelating ability respectively

low adherence in the developing countries [36]. Consistent intake of fruits has been linked to reduced risks of stroke, cardiovascular disease, cancer, cataracts, neurodegenerative disease, and some of the functional degenerations linked with aging [37]. Phytochemicals, water, fiber, sugars, and vitamin $\mathrm{C}$ are usually high in fruits. The process of ripening in fruits resulting from starch hydrolysis to sugar can increase the sugar content in most fruits [38]. Therefore, this could be a possible reason for the low starch and high sugar contents of the fruits parts used for the analysis. This corroborates the findings of Oboh et al. [39] who explained that starch is converted to reduced sugar following fruit ripening. It has been found that in comparison with other similar products which are high in amylopectin, products that are high in amylose induce low insulin responses and blood glucose. In this study, despite the higher content of amylopectin compared to amylose, the fruits parts showed a potentially good response to hyperglycemia. This could be ascribed to other constituents, including fiber and phenolic, which, according to previous studies, could help to lower blood glucose [40, 41]. It has also been reported that compared to foods with low amylose content, food with higher amylose content has lower digestibility [42, 43], and this could be an important justification for the use in aiding digestion.

The estimated glycemic index (eGI) portrays the carbohydrates consumed in diverse food types on the basis of postprandial blood glucose level [43, 44]. Dietary changes are often essential for controlling type- 2 diabetes, regardless of the insulin requirement. The eGI was expressed in an effort to help those that are diabetic with their choices of food based on the recommendation that they select foods with a low GI [45]. In this study, the pulp coats which are usually disposed recorded the lowest eGI. Thus, it may be suggested for consumption for those who are diabetic. This result also corroborates the findings of Oboh et al. [39] who reported a low eGI in African star apple fruit. The lowest eGI in the pulp coat could be due to the presence of polyphenols, sucrose, and fibers. Previous studies have also revealed that low-GI diets have the tendency of increasing glycemic control in people who have low tolerance to glucose and type-II diabetes by reducing fasting blood glucose and
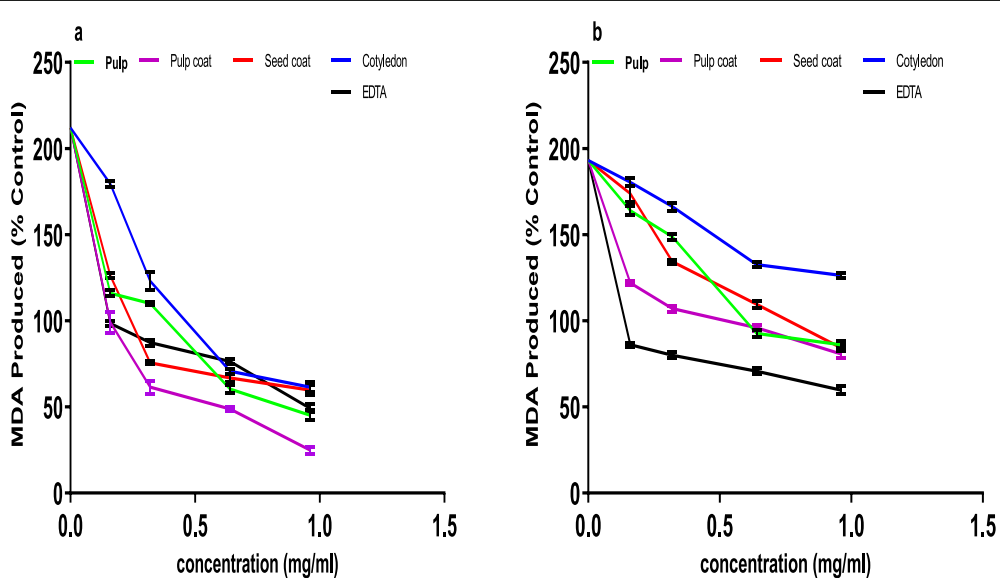

Fig. 2 (a) Fe ${ }^{2+}$-induced MDA inhibition and (b) SNP-induced MDA inhibition of extract from African star apple fruit parts in rat pancreas tissue homogenate. Values represent means \pm standard deviation of triplicate readings 
Table 4 Effective concentration causing $50 \%$ antioxidant ability ( $I C_{50}$ values) of aqueous extract of different parts of ripe African star apple fruit on inhibition of FeSO4 and SNP-induced lipid peroxidation in rat's pancreas

\begin{tabular}{lll}
\hline Sample & $\mathrm{FeSO}_{4}$-Induced lipid peroxidation $(\mathrm{mg} / \mathrm{ml})$ & SNP-induced lipid peroxidation $(\mathrm{mg} / \mathrm{ml})$ \\
\hline Pulp & $0.54 \pm 0.08^{a}$ & $0.63 \pm 0.14^{a}$ \\
Cotyledon & $0.64 \pm 0.17^{b}$ & $0.89 \pm 0.13^{b}$ \\
Seed coat & $0.68 \pm 0.15^{b}$ & $0.91 \pm 0.15^{b}$ \\
Pulp coat & $0.34 \pm 0.07^{c}$ & $0.49 \pm 0.11^{c}$ \\
EDTA & $0.48 \pm 0.04^{a}$ & $0.32 \pm 0.10^{d}$ \\
\hline
\end{tabular}

The $\mathrm{IC}_{50}$ (effective concentration causing $50 \%$ antioxidant ability) were calculated using nonlinear regression analysis. Values represent mean \pm standard deviation $(n=3)$. Values with the same letter within a column are not significantly different $(p>0.05)$. Positive control: EDTA (Ethylenediaminetetraacetic acid)

glycated proteins and also cause insulin sensitivity to improve.

In the onset, Chronic hyperglycemia was implicated as well as the pathogenesis of diabetes and its associated complications [46]. There are signs that chronic hyperglycemia can induce the creation of species with reactive oxygen and eventually result in pancreatic cell damage and oxidative stress $[9,46]$. The radical scavenging activities exhibited by the fruit parts observed in this study corroborates the results of Oboh et al. [39] who found that fruits possess antioxidant properties. The radical scavenging activity of the fruit parts has strong relationship with the vitamin $\mathrm{C}$ and phenolic contents. Furthermore, past studies have presented ascorbic acid as a strong antioxidant and scavenger of oxygen-determined radicals, for example, hydroxyl $(\mathrm{OH})$ radical and singlet oxygen [47], in spite of the fact that the antioxidant properties of numerous plants with their radical scavenging capacity have been connected to their phenolic content $[7,48]$. The finding that sodium nitroprusside (SNP) and iron led to a significant rise in the content of MDA in the pancreas corroborates with earlier findings where iron was found to be a potential initiator of lipid peroxidation [21]. The increase in lipid peroxidation in the presence of iron could be ascribed to the iron's ability to catalyze one-electron transfer reactions which produce ROS, for instance, the reactive hydroxyl radical that is produced from $\mathrm{H}_{2} \mathrm{O}_{2}$ through the Fenton reaction. Iron also decomposes lipid peroxides, thereby producing alkoxyl and peroxyl radicals, which supports lipid oxidation propagation [49]. In the pancreas, iron accumulates in acinar cells and in the Islets of Langerhans. This leads to the damage of the $\beta$-cells related to diabetes mellitus [50]. Thus, the reduction of iron could prompt a reduction in oxidative stress in the entire body [51]. Nevertheless, the crude extracts from the various parts of African star apple fruit led to a dose-dependent reduction (which was significant at $5 \%$ ) in the content of MDA of the SNP and $\mathrm{Fe}^{2+}$-stressed pancreas homogenates. It is difficult to categorically state the means by which $\mathrm{Fe}^{2+}$-induced lipid peroxidation is inhibited. However, it is possible for the water extractable phytochemicals to have formed complexes with the iron, thus stopping them from catalyzing the instigation of lipid peroxidation and/or it is also possible for the phytochemical to have scavenged the free radical generated by the $\mathrm{Fe}^{2+}$-catalyzed reaction [21]. Glucose, in the presence of transition metals (e.g. Fe), can be oxidized to produce ROS, which has been implicated in the advancement of diabetic complications as well as diabetes itself. Excess cytosolic iron is a common factor of gestational diabetes [52] and a vivid risk factor for the disease in normal populations [53]. Insulin sensitivity is improved by lowering iron [53]. Therefore, the status of iron may be a major factor in the development of type II diabetes [53]. There is also a possibility for Iron to be included in the Fenton reaction which leads to the production of hydroxyl radical. These radicals subsequently attack DNA, protein, membrane lipids and many other biomolecules which are important physiologically.

Table 5 Effective concentration causing 50\% inhibitory ability ( $\left(C_{50}\right.$ values) of a-amylase and a-glucosidase inhibitory activities of fruits parts

\begin{tabular}{lll}
\hline Sample & a-amylase inhibitory activity $(\mathrm{mg} / \mathrm{ml})$ & a-glucosidase inhibitory activity $(\mathrm{mg} / \mathrm{ml})$ \\
\hline Pulp & $1.46 \pm 0.16^{a}$ & $1.48 \pm 0.17^{a}$ \\
Cotyledon & $3.96 \pm 0.59^{b}$ & $2.29 \pm 0.35^{b}$ \\
Seed coat & $4.16 \pm 0.62^{c}$ & $1.79 \pm 0.25^{c}$ \\
Pulp coat & $1.39 \pm 0.14^{d}$ & $1.35 \pm 0.13^{d}$ \\
Acarbose & $1.20 \pm 0.08^{e}$ & $1.55 \pm 0.19^{c}$ \\
\hline
\end{tabular}

The $\mathrm{IC}_{50}$ (effective concentration causing 50\% inhibitory ability) were calculated using nonlinear regression analysis. Values represent mean \pm standard deviation $(n=3)$. Values with the same letter within a column are not significantly different $(p>0.05)$ 
Table 6 Phenolic components of aqueous extract of African star apple fruit parts

\begin{tabular}{|c|c|c|c|c|}
\hline \multirow[t]{2}{*}{ Compounds } & \multicolumn{2}{|c|}{ African star apple fruit parts } & \multirow[b]{2}{*}{ Seed coat mg/g } & \multirow[b]{2}{*}{ Pulp coat $\mathrm{mg} / \mathrm{q}$} \\
\hline & Pulp mg/g & Cotyledon mg/g & & \\
\hline Beta-amyrin acetate & $2.42 \pm 0.03 a$ & $4.24 \pm 0.01 a$ & $2.83 \pm 0.02 a$ & $2.66 \pm 0.01 a$ \\
\hline Eleagnine & $0.86 \pm 0.01 b$ & $0.34 \pm 0.03 b$ & $1.46 \pm 0.01 a$ & $1.31 \pm 0.01 a$ \\
\hline Epicatechin & $0.98 \pm 0.02 b$ & $1.39 \pm 0.02 c$ & $1.27 \pm 0.02 b$ & $1.24 \pm 0.03 a$ \\
\hline Epigallocatechin & $0.78 \pm 0.01 b$ & $0.34 \pm 0.01 b$ & $0.97 \pm 0.02 c$ & $0.87 \pm 0.02 b$ \\
\hline Gentisic Acid & - & $0.67 \pm 0.02 b$ & $0.44 \pm 0.02 c$ & $0.21 \pm 0.01 c$ \\
\hline Myricetin rhamnoside & $0.50 \pm 0.02 c$ & - & $0.78 \pm 0.02 c$ & $0.64 \pm 0.02 b$ \\
\hline Procyanidin $\mathrm{B}_{5}$ & - & - & $0.54 \pm 0.01 c$ & $0.54 \pm 0.01 b$ \\
\hline Skatole & $0.84 \pm 0.01 b$ & $0.32 \pm 0.01 b$ & $1.59 \pm 0.02 b$ & $1.49 \pm 0.02 a$ \\
\hline Stigmasterol & $3.74 \pm 0.02 a$ & $2.47 \pm 0.02 \mathrm{a}$ & $5.82 \pm 0.02 d$ & $5.25 \pm 0.02 d$ \\
\hline Tetrahydro-2-methylharman & $1.05 \pm 0.01 \mathrm{a}$ & $0.35 \pm 0.01 b$ & $1.66 \pm 0.03 a$ & $1.59 \pm 0.03 a$ \\
\hline
\end{tabular}

Results are expressed as mean \pm standard deviations (SD) of three determinations. Averages followed by different letters differ by Tukey test at $\mathrm{p}<0.05$

Hyperglycemia is caused by degradation of foods which are starchy by carbohydrate-hydrolyzing enzymes (such as $\alpha$-glucosidase and $\alpha$-amylase). The common therapeutic approaches applied in treating and managing diabetes includes using synthetic inhibitors of $\alpha$ glucosidase and $\alpha$ - amylase activities to slow the rate at which glucose is released into the blood stream [39]. According to Saito et al. [54], using these synthetic inhibitors (such as voglibose and acarbose) presents some side effects like flatulence, meteorism, and abdominal cramps. Managing diabetes taking a dietary approach by using plants that have natural inhibitors of $\alpha$ - glucosidase and $\alpha$-amylase is more advantageous. Our findings indicate that the fruit parts also displayed their ability to inhibit $\alpha$-glucosidase and $\alpha$-amylase activities in vitro. However, of all the fruit parts, the pulp coat indicated the highest inhibitory activity on $\alpha$-amylase. Likewise, a similar trend was found for $\alpha$-glucosidase inhibitory activity. Studies have shown fruits to have various health benefits, with antidiabetic effect inclusive [55, 56].

The antioxidant qualities of plant foods have been associated with the presence of an array of important phenolic and non-phenolic phytochemicals such as

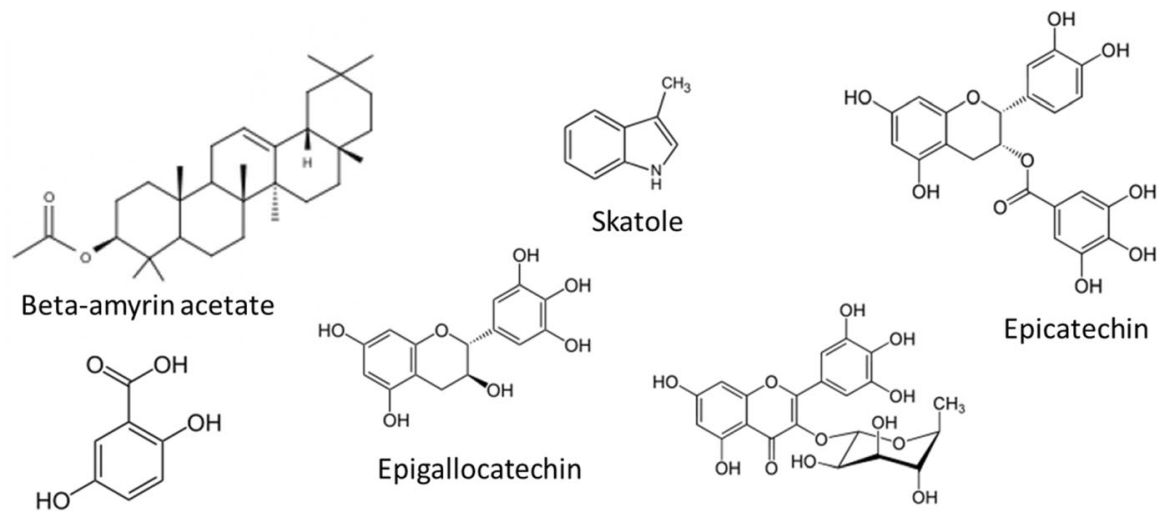

Gentisic Acid OH

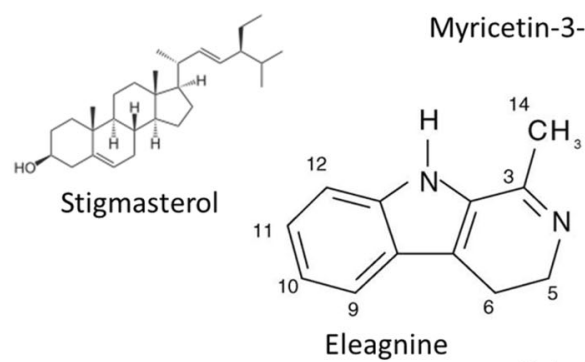<smiles>CC1NCCc2c1[nH]c1ccccc21</smiles>

Tetrahydro-2-methylharman

Fig. 3 Structures of compounds identified in Chrysophyllum albidum fruit parts, Source: ChemSpider 
alkaloids, phenolic acids, and flavonoids [57, 58]. However, classification of the extracts with HPLC showed that the major constituent of the pulp, cotyledon, seed coat and pulp coat of ripe African star apple fruit are Beta-amyrin acetate, eleagine, epicatechin, epigallocatechin, skatole, stigmasterol and tetrahydro - 2- methyl harman (Table 6). Historically, phenolic fractions of plants are recognized as inhibitors of carbohydrate hydrolyzing enzymes in higher animals. Phenolic compounds derived from raspberries, red cabbage, and strawberries are recognized as inhibitors of $\alpha$ glucosidase and $\alpha$-amylase [55]. Though Jenkins et al. [44] confirmed that as far as managing diabetes is concerned, the notion of glycemic index is not new and adoption of pharmacologic methods to slow the absorption of carbohydrate, most especially using glycoside inhibitors, are currently recognized in diabetes management, it is worth noting that the current study was able to elucidate the eGIs, antioxidant properties as well as $\alpha$-amylase and $\alpha$-glucosidase inhibitory properties of Africa star apple fruit parts. In this regard, the study established a connection between the eGI and the hypoglycemic potential of fruit parts, affirming that the fruit parts will be excellent inhibitors of starch hydrolyzing enzymes due to their low eGI and hence possess great potentials in the management of Diabetes Mellitus.

\section{Conclusion}

African star apple fruit parts (pulp, cotyledon, seed coat and pulp coat) exhibited significant antioxidant activities as revealed by their ability to scavenge free radicals as well as their effective ferric reducing power. The low glycemic indices, and the inhibitory effects of the fruit parts on carbohydrate hydrolyzing enzymes ( $\alpha$-amylase and $\alpha$ glucosidase) due to their phytochemical constituents showed that the fruit parts can be of great benefit as functional dietary supplement to manage or control diabetes-related disorders. Overall, African star apple pulp coat exhibited superior properties and may serve as an important food supplement for health promotion. Hence, further studies on the toxicity studies on different parts of the fruit used in this study should be carried out to ascertain their safety.

\section{Abbreviations}

ABTS: 2, 2'-azino-bis (3-ethylbenzothiazoline-6-sulphonic acid); DM: Diabetes Mellitus; eGI: Estimated glycemic index; Fe ${ }^{2+}$ : Iron (II) chelating ability; NO: Nitric oxide; $\mathrm{OH}$ : Hydroxyl; SNP: Sodium nitroprusside

\section{Acknowledgements}

The authors wish to thank the laboratory assistant for providing us with all necessary equipment's required for the study as well as the support by the support by the grants from TETFund Institutional Based Research, Ekiti State University, Ado Ekiti, Nigeria. TETFund Reference Number: Tetfund 2016/2017 Intervention year.

\section{Authors' contributions}

ASF carried out the study, wrote the manuscript, carry out analysis and interpretation of data, $A O B$ assisted with and supervised the manuscript writing, OFL did the first proof reading and $A O B$ did the second proof reading. The authors read and approved the final manuscript.

\section{Funding}

This work was financially supported through funding received from tertiary education trust fund (TETFund) Institutional Based Research, Ekiti State University, Ado Ekiti, Nigeria. TETFund Reference Number: Tetfund 2016/2017 Intervention year. The contents of the manuscript are solely the responsibility of the authors and do not necessarily represent the official views of the funding body.

\section{Availability of data and materials}

The datasets used to analyze during this study are available from the corresponding author on reasonable request.

Ethics approval and consent to participate

This study was done in compliance with the ethical committee of Ekiti State University, Ado-Ekiti, Ekiti State, Nigeria.

\section{Consent for publication}

Not applicable.

\section{Competing interests}

The authors declare that they have no competing interests.

Received: 16 April 2020 Accepted: 12 August 2020

Published online: 25 August 2020

\section{References}

1. Watcharachaisoponsiri T, Sornchan P, Charoenkiatkul S, Suttisansanee U. The a-glucosidase and a-amylase inhibitory activity from different chili pepper extracts. Int Food Res J. 2016:23(4):1439-45.

2. Oyetayo FL, Akomolafe SF, Odeniyi IA. Effects of dietary supplementation of Chrysophyllum albidum fruit pulp powder on some biochemical parameters in a type 2 diabetes rat model. Vegetos. 2019;2019. https://doi.org/10.1007/ s42535-019-00022-7.

3. Ademiluyi AO, Oyeleye SI, Oboh G. Biological activities, antioxidant properties and phytoconstituents of essential oil from sweet basil (Ocimum basilicum L.) leaves. Comp Clin Pathol. 2016;25(1):169-76.

4. Adefegha SA, Oboh G, Ejakpovi II, Oyeleye SI. Antioxidant and antidiabetic effects of gallic and protocatechuic acids: a structure-function perspective. Comp Clin Pathol. 2015;24(6):1579-85.

5. Malviya N, Jain S, Malviya S. Antidiabetic potential of medicinal plants. Acta Pol Pharm. 2010;67(2):113-8.

6. Valls-Pedret C, Lamuela-Ravent'os RM, Medina-Rem'on A. Polyphenol-rich foods in the mediterranean diet are associated with better cognitive function in elderly subjects at high cardiovascular risk. J Alzheimers Dis. 2012:29(4):773-82

7. Oboh, Akinbola IA, Ademosun AO. Essential oil from clove bud (Eugenia aromatica Kuntze) inhibit key enzymes relevant to the management of type-2 diabetes and some pro-oxidant induced lipid peroxidation in rats pancreas in vitro. J Oleo Sci. 2015a;64(7):775-82

8. Singh $S$, Immanuel $G$. Extraction of antioxidants from fruit peels and its utilization in paneer. J Food Process Technol. 2014;5:349. https://doi.org/10. 4172/2157-7110.1000349

9. Oboh G, Ademiluyi AO, Ademosun AO. Phenolic extract from Moringa oleifera leaves inhibits key enzymes linked to erectile dysfunction and oxidative stress in rats' penile tissues. Biochem Res Int. 2015;2015:Article ID 1759508 pages.

10. Adebayo AH, Aliyu R, Gatsing D, Garba $I H$. The effects of ethanolic leaf extract of Chrysophyllumalbidum on biochemical and haematologicalparameters of albino Wistar rats. Afr J Biotechnol. 2006;9: 2145-50.

11. Florence $A B$, Adiaha $A H$. Storage effects and the postharvest quality of African star apple fruits (Chrysophyllum africanum) under ambient conditions. Afr J Food Sci Technol. 2015;6(1):35-40. 
12. Okoli BJ, Okere OS. Antimicrobial activity of the phytochemical constituents of Chrysophyllum albidum Plant.Jour.Of research in Nat. Deve. 2010;8(1): 1035-7.

13. Olorunnisola DS, Amao IS, Ehigie DO, Ajayi ZAF. Anti-hyperglycaemic and hypolipidemic effect of ethanolic extract of Chrysophyllum albidumseed cotyledon in alloxan induced-diabetic rats. Res. J Appl Sci. 2008;3:123-7.

14. Akubugwo IE, Ugbogu AE. Physicochemical studies on oils from five selected Nigerian plant seeds. Pak J Nutr. 2007;6:75-8.

15. Oboh G, Adebayo AA, Ejakpovi II, Ogunsuyi OB, Boligon AA. Phenolic profiling and in vitro antioxidant, anticholinesterase, and antimonoamine oxidase properties of aqueous extract of African star apple (Chrysophyllum albidum) fruit parts. 2018;42(4):e12568. https://doi.org/10.1111/jfbc.12568.

16. $\mathrm{HO} \mathrm{I}, \mathrm{O} \mathrm{O}, \mathrm{OO}$ A, FD O, KO K, LB M. Nutrients compositions and phytochemical contents of edible parts of Chyrsophyllum albidum fruit. J Nutr Food Sci. 2017:7:579-87.

17. Abiodun OA, Oladapo AS. Physicochemical properties of African star apple (Chrysophylum albidum) components. Nutr Food Sci. 2011:41:8-11.

18. Shobo AA, Daniyan MO, Olayiwola G. Toxicity evaluation of the extract and fraction of Chrysophyllum Albidum seed cotyledons in rats. SOJ Pharm Sci. 2019;6(1):1-12. https://doi.org/10.15226/2374-6866/6/1/00194

19. Arueya GL, Ugwu GF. Development and evaluation of African star apple (Chrysophyllum albidum) based food supplement and its potential in combating oxidative stress. J Funct Foods. 2017;33:376-85.

20. Asare IK, Okyere AA, Duah-Bissiw D, Ofosu DO, Darfour B. Nutritional and phytochemical constituents of the African star apple (Chrysophyllum albidum G. DON); 2015

21. Oboh G, Puntel RL, Rocha JBT. Hot pepper (Capsicum annuum, tepin and Capsicum chinese, Habanero) prevents $\mathrm{Fe}^{2+}$-induced lipid peroxidation in brain in vitro. Food Chem. 2007;102:178-85.

22. Adefegha SA, Oboh G, Oyeleye SI, Ejakpovi I. Erectogenic, antihypertensive, antidiabetic, anti-oxidative properties and phenolic compositions of almond fruit (Terminalia catappa L.) parts (Hull and drupe)-in vitro. J Food Biochem. 2016a:e12309. https://doi.org/10.1111/jfbc.12309.

23. Akomolafe SF. Ajayi OB. A comparative study on antioxidant properties, proximate and mineral compositions of the peel and pulp of ripe Annona muricata (L.) fruit. Int Food Res J. 2015;22(6):2381-8.

24. Akomolafe SF, Oboh G, Oyeleye SI, Molehin OR, Opeyemi B. Phenolic composition and inhibitory ability of Methanolic extract from pumpkin (Cucurbita pepo $L$ ) seeds on Fe-induced Thiobarbituric acid reactive species in albino Rat's testicular tissue in-vitro. J Appl Pharmaceutical Sci. 2016b;6(9):115-20.

25. Oboh G, Akinyemi AJ, Adeleye B, Oyeleye SI, Ogunsuyi OB, Ademosun AO, et al. Polyphenolic compositions and in vitro angiotensin-l-converting enzyme inhibitory properties of common green leafy vegetables: a comparative study. Food Sci Biotechnol. 2016;25(5):1243-9.

26. Akomolafe SF, Oboh G, Oyeleye SI, Boligon AA. Aqueous extract from Ficus capensis leaves inhibits key enzymes linked to erectile dysfunction and prevent oxidative stress in rats' penile tissue. NFS J. 2016a;4:15-21.

27. Akomolafe SF, Oboh G, Akindahunsi AA, Afolayan AJ. Tetracarpidium conophorum (Mull.Arg) Hutch \& Dalziel inhibits FeSO4 -induced lipid peroxidation in rat's genitals. BMC Complement Altern Med. 2015;15:57. https://doi.org/10.1186/s12906-015-0547-1.

28. Halliwell B, Gutteridge JMC, Aruoma Ol. The deoxyribose method: simple test-tube assay for determination of rate constant $\mathrm{s}$ for reactions of hydroxyl radicals. Anal Biochem. 1987;165:215-9.

29. Kilkenny C, Browne WJ, Cuthill IC, Emerson M, Altman DG. Improving bioscience research reporting: the ARRIVE guidelines for reporting animal research. PLoS Biol. 2010;8:e1000412.

30. Akomolafe S, Oboh G, Olasehinde T, Oyeleye S, Ogunsuyi O. Modulatory effects of aqueous extract from Tetracarpidium conophorum leaves on key enzymes linked to erectile dysfunction and oxidative stress-induced lipid peroxidation in penile and testicular tissues. J Appl Pharmaceut Sci. 2017; 7(1):051-6.

31. Dada FA, Oyeleye SI, Ogunsuyi OB, Olasehinde TA, Adefegha SA, Oboh G, et al. Phenolic constituents and modulatory effects of raffia palm leaf (Raphia hookeri) extract on carbohydrate hydrolyzing enzymes linked to type-2 diabetes. J Tradit Complement Med. 2017;7:494-500.

32. Onitilo MO, Sanni LO, Daniel I, Maziya-Dixon B, Dixon A. Physicochemical and functional properties of native starches fromcassava varieties in Southwest Nigeria. J Food, Agric Environ. 2007;5(3-4):108-14.

33. Juliano BO. A simplified assay formilled-rice amylose. Cereal Sci Today. 1971; 16:334-8.
34. Brouns F, Bjorck I, Frayn KN. Glycaemic index methodology. Nutr Res Rev. 2005;18(1):145-71.

35. Kelley WI, Coffey DL, Mueller TC. Liquid chromatographic determination of phenolic acids in soil. J AOAC Int. 1994:77:805-9.

36. WHO. Promoting fruits and vegetables consumption around the world. A joint meeting of WHO/FAO on fruits and vegetables for health improvement Kobe, Japan; 2004

37. Liu RH. Health benefits of fruit and vegetables are from additive and synergistic combinations of phytochemicals. Am J Clin Nutr. 2003; 78(3(Suppl)):517S-20S

38. Hulme AC. The biochemistry of fruits and their products 1. London: Academic; 1970

39. Oboh G, Ademosun AO, Akinleye M, Omojokun OS, Boligon AA, Athayde ML. Starch composition, glycemic indices, phenolic constituents, and antioxidative and antidiabetic properties of some common tropical fruits. J Ethn Foods. 2015;2:64-73.

40. Oboh G, Ademosun AO, Ademiluyi AO, Omojokun OS, Nwanna EE, Longe KO. In vitro studies on the antioxidant property and inhibition of a-amylase, aglucosidase and angiotensin i-converting enzyme by polyphenol-rich extracts from cocoa (Theobroma cacao) bean. Pathol Res Intl. 2014;2014:549287.

41. Mclvor ME, Cummings CC, Leo TA, Mendeloff Al. Flattening postprandial blood glucose responses with guar gum: acute effects. Diabetes Care. 1985:8:274e8.

42. Frei $M$, Siddhuraju P, Becker K. Studies on in vitro starch digestibility and the glycemic index of six different indigenous rice cultivars from the Philippines. Food Chem. 2003;83:395-402.

43. Hu P, Zhao H, Duan Z, Linlin Z, Wu D. Starch digestibility and the estimated glycemic score of different types of rice differing in amylose content. J Cereal Sci. 2004;40:231-7.

44. Jenkins DJ, Kendall CW, Augustin LS, Franceschi S, Hamidi M, Marchie A, et al. Glycemic index: overview of implications in health and disease. Am J Clin Nutr. 2002;76:266S-73S.

45. Thorne MJ, Thompson LU, Jenkins DJA. Factors affecting starch digestibility and the glycemic response with special reference to legumes. Am J Clin Nutr. 1983;38:481-8.

46. Valko M, Leibfritz D, Moncol J, Cronin MTD, Mazur M, Telser J. Free radicals and antioxidants in normal physiological functions and human disease. Int J Biochem Cell Biol. 2007:39(1):44-84.

47. Arrigoni O, De Tullio MC. Ascorbic acid: much more than just an antioxidant. Biochim Biophys Acta Gen Subj. 2002;1569(1-3):1-9.

48. Ademosun OA, Oboh G, Adewuni TM, Akinyemi AJ, Olasehinde TA. Antioxidative properties and inhibition of key enzymes linked to type-2 diabetes by snake tomato (Tricosanthes cucumerina) and two tomato (Lycopersicon esculentum) varieties. Afr J Pharm Pharmacol. 2013;7(33):2358-65.

49. Zago MP, Verstraeten SV, Oteiza PI. Zinc in the prevention of $\mathrm{Fe}^{2+}$ initiated lipid and protein oxidation. Biol Res. 2000;33:143-50.

50. Shah SV, Fonseca VA. Iron and diabetes revisited. Diabetes Care. 2011;34:1676-7.

51. Minamiyama $Y$, Takemura S, Kodai S. Iron restriction improves type 2 diabetes mellitus in Otsuka long-Evans Tokushima fatty rats. Am J Physiol Endocrinol Metab. 2010;298:1140-9.

52. Lao T, Chan PL, Tam KF. Gestational diabetes mellitus in the last trimester - a feature of maternal iron excess? Diabet Med. 2001;18:218-23.

53. Ferna'ndez-Real JM, Lo'pez-Bermejo A, Ricart W. Cross-talk between iron metabolism and diabetes. Diabetes. 2002:51:2348-54.

54. Saito N, Sakai H, Sekihara H, Yajima Y. Effect of an a-glucosidase inhibitor (Voglibose), in combination with sulphonyl urea, on glycemic control in type 2 diabetes patients. J Int Med Res. 1998;26:219-32.

55. McDougall GJ, Shpiro F, Dobson P, Smith P, Blake A, Stewart D. Different polyphenolic components of soft fruits inhibit alpha-amylase and alphaglucosidase. J Agric Food Chem. 2005;53:2760-6.

56. Adeyemi DO, Komolafe OA, Adewole OS, Obuotor EM, Adenowo TK. Anti hyperglycemic activities of Annona muricata (Linn). Afr J Trad Complement AltMed. 2009;6:62-9.

57. Cheplick S, Kwon Y, Bhowmik P, Shetty K. Clonal variation in raspberry fruit phenolics and relevance for diabetes and hypertension management. J Food Biochem. 2007:31:656-79.

58. Chu Y, Sun J, Wu X, Liu RH. Antioxidant and antiproliferative activity of common vegetables. J Agric Food Chem. 2002;50:6910-6.

\section{Publisher's Note}

Springer Nature remains neutral with regard to jurisdictional claims in published maps and institutional affiliations. 